\title{
The Urgency of the Public-Private Partnership Scheme in the Management of Electronic Parking in Bandung City
}

\author{
Joni Dawud*, Deni Fauzi Ramdani, Rodlial Ramdhan Tackbir Abubakar \\ Politeknik STIA LAN Bandung \\ Bandung, Indonesia \\ *jonidawud@ poltek.stialanbandung.ac.id, deni.fauzi@poltek.stialanbandung.ac.id, rodlial.ramdhan@ stialanbandung.ac.id
}

\begin{abstract}
Optimizing revenue from parking fees is expected to increase local revenue. The Bandung City Government made a breakthrough, including electronic parking and institutional changes to become a Local community service agency. In the implementation of this electronic parking, there are many obstacles so that the achievement does not match the expected target. This article is an initial study of the problem of electronic parking which is considered not running well. This study employed a qualitative descriptive approach by collecting primary and secondary data from informants. The result of this study emphasized the importance of private government cooperation in managing parking as a public-private partnership scheme accompanied by changes in regulations, institutions, and relationships between parties involved in electronic parking management policies.
\end{abstract}

Keywords-local government, electronic parking, public-private partnership

\section{INTRODUCTION}

Since the beginning of Bandung Mayor Ridwan Kamil's leadership in 2014, his government had been active in leading the city of Bandung towards a Smart City. The Mayor of Bandung, Ridwan Kamil, was very serious in developing this concept. It could be seen from every program and policy leading to the smart city program that has been designed since the beginning. The approach taken by Ridwan Kamil was often presented in various forums in the terms collaboration, decentralization, and innovation [1].

Among the innovations that encouraged the Smart City Government of Bandung City in early 2014 was to test the use of electronic parking on Jalan Braga as a solution to increasing revenue from the parking sector and reducing the leakage rate of parking fees. It turns out that the results were satisfactory with the estimation of getting multiple parking optimization.

At the beginning of the idea of using electronic parking, the Bandung City government decided to increase the number of parking machines using an investment auction scheme. In mid2015 , the winner of the investment auction had been obtained.
In early 2016 there was a change in the head of the transportation agency. 15 contract items had to be discussed intensively, until the remaining 4 contracts to be discussed with the regional secretary stated by Didi on 2020 .

Furthermore, among the contract clauses in the business calculation, it was agreed that the direct revenue sharing of $70 \%$ is for electronic parking equipment providers, namely investors. Meanwhile, the government only gets 30\% profit for the regional treasury. After conducting an in-depth discussion, it turned out that revenue using user fees could not be shared. The regulation requires that all retribution revenue must go $100 \%$ to the regional treasury. Investors are paid through spending from the Regional Revenue and Expenditure Budget (APBD). Because it is paid by the APBD, investors are subject to a 10\% Value Added Tax (VAT). Investors asked for the tax to be abolished because it was not included in the clause, the government did not approve of this. As a result, no understanding was reached and termination was made, it ended not being continued. The public-private cooperation scheme did not work and continued.

On the other hand, it turns out that the regional legislative council of Bandung City (DPRD) conducted a joint study by one of the universities which stated that the potential for onstreet parking in the City of Bandung was IDR 85 billion stated by Didi on 2020. Finally, the procurement was carried out under the Government's scheme of self-management by UPT of parking. 445 Parking machines began operating in 2017.

After one month of operation, the parking income did not experience a significant change. It turns out that, in practice, many obstacles occur in the field. So that the current emerging schemes do not add value to of Regional Fixed Income targeted.

Problems range from undisciplined parking attendants, level of public awareness, and many interest groups involved in the parking management system that are not running well.

This article conducts an initial study of the importance of changing a scheme that is only self-managed by the Bandung 
City government into electronic parking management by a third party with a public-private partnership (PPP) scheme. The Public-Private Partnership development pattern is considered to be effective in solving the problems of current electronic parking management.

Not many articles have discussed the public-private partnership (PPP) scheme, especially related to parking management. Some of the articles include the Public-Private Partnership development pattern at PDAM Tirta Tara which was built through an addendum, an addendum was obtained from the negotiation process which resulted in a win-win solution to overcome problems and changes in situations and conditions that affect the Public-Private Partnership scheme. The addendum is strengthened through collaborative excellence that serves to manage goals, create trust, build culture, and manage technology. The critical success factors in the Public-Private Partnership are risk allocation, adequate legal framework, availability of financial markets [2].

There is also another article with the same locus in Bandung City and focuses on the Public-Private Partnership scheme regarding the steps forward for the Bandung City government by compiling clear guidelines and details of projects offered under the PPP scheme in infrastructure projects. However, the result showed that there are not many projects that can be financed by this scheme. Nonetheless, it has given new confidence that local governments are capable and need to work on infrastructure development through the PPP scheme [3].

Furthermore, another article also discussed the perceptions of public and private institutions on the risks affecting the duration of the contract and how the duration of the contract affects private investment. The results showed that a wellstructured long-term contract can: 1) provide the risk mitigation mechanisms needed for both public and private actors, and 2) facilitate private investment from the supplier side [4].

Other research that can be used as an important reference is related to the existence of electoral cycles and political connections which leads to strategic behavior by the public sector aimed to please voters and private entities. It often capitalizes on the fact that the government is incapable of disrupting public services before elections. Bargaining power is held primarily by private companies/consortia of companies that charge additional leases to compensate for the underbidding of the initial bidding round. When the consortium is dominated by foreign companies, the frequency of negotiations is higher but the extraction of leases from renegotiations is lower, reflecting a lower degree of political engagement. Experience with PPP projects does not reduce the likelihood of further renegotiation. Despite recommendations from the PPP supervisor (Court of Audit), the public sector has not made improvements in contract design and PPP contract renegotiation clauses [5].

The results of the linear regression analysis conducted by Kirschner \& Lanzendorf [6] showed that the residents have the intention to change their behavior towards reducing car use, assessing the policy options of reducing car speed and increasing regular bicycle users. These findings suggest that even though residents support on-street parking policies if reuse of parking spaces creates space for other users or if it improves the quality of life, for example, by adding bike lanes, wider sidewalks, or greenery. Therefore, a combination of restrictive and demand-oriented on-street parking policies generates high acceptance among residents, and communications from municipalities regarding the implementation of different policies need to vary depending on the type of household.

Parking pricing is considered a powerful tool for improving parking management and reducing traffic congestion in metropolitan areas. A study conducted by Wang, Li, Wang, \& Shang [7], on the implementation of a new parking price policy in Nanning to investigate the effect of time variation of price on on-street parking characteristics, including parking duration and parking turnaround, showed that parking duration decreases with increasing parking prices, with a correlation that shows increased elasticity. The fluctuating elasticity of parking rotation may be due to the influence of vehicle ownership. Strategies that can improve parking services are also researched based on empirical data and modeling results.

This article tries to describe the problem of parking management as an on-street parking policy on the characteristics of city residents that are not improving with a collaborative management approach between the government and the private sector. This study is expected to become a recommendation in governance based on the new public services paradigm

\section{METHODS}

This article employed a qualitative descriptive approach that seeks to describe the potential of Electronic Parking in Bandung City and a development model for collaboration management in public service governance. The data collection techniques are carried out through primary and secondary data inventory. The Primary data collection was obtained from field empirical data through in-depth interviews and non-participant observations of stakeholders who are directly related to informants involved in energy development. The Secondary data was obtained through tracing various government documents, literature, print and electronic media coverage, journals, and books related to EBT policies as a field data search application. Furthermore, the data collected were analyzed with qualitative analysis based on the interactive model of Miles and Huberman [8].

\section{RESULTS AND DISCUSSION}

The parking management of the Bandung City Government is divided into two, namely the management of on-street and off-street parking. On-street parking management is regulated and implemented by the Transportation Agency as a potential retribution. Meanwhile, off-street parking management is used 
as an object of taxpayers managed by the Regional Revenue Management Agency (BPPD) of Bandung City. Electronic parking is used as a method to facilitate on-street parking which was previously done by manual parking attendants. Initially, the use of electronic parking is expected to increase revenue in parking fees. However, on its way, many problems encountered, starting from the very low awareness of the public in using electronic parking, until other actors were affected. As a result, many parties reduce their role and become part of the resistance to the smooth operation of this electronic parking. Institutionally, it has not fully supported a more professional performance process. So the urgency of changing the scheme into public-private cooperation is an alternative solution in the management of electronic parking for on-street parking.

\section{A. Challenges and Opportunities in Electronic Parking Management}

Electronic parking management has been stuck in its application because it encountered many obstacles. The preliminary study stated that the potential income from onstreet parking was 85 billion by one of the universities. However, the results of the study are still questionable, so where do these figures come from? Even though there are many things to consider when parking management is carried out, in people's opinion, parking can be said to have a great effect on the livelihoods of people. Lack of mapping of the problem from the start has led the current electronic parking hampered. Based on the sources of the informants, in several points, at least it must take into account who is directly involved. Besides parking attendants, there are also mass organizations, officials, or other parties who affect how much parking fees must be set aside. Even though, for example, at one point of parking, some parking officers routinely ask for cigarettes whose value is insignificant, if they are accumulated it will affect the parking attendant's performance.

Although the work supervision of parking attendants and sector heads are also carried out by the Parking Management Unit, this method of monitoring is carried out periodically. Every time a deposit is withdrawn, it is carried out by the Head Sector (Kator). If there is a violation found, it should be done by a parking attendant. The various strategies undertaken to manage the parking lot in Bandung have not been implemented optimally. The problems that exist are not only regarding the number of funds that go to the regional treasury but are related to order, security, beauty, and smoothness of traffic.

There is a need for a joint commitment, not only by the leadership but also the parking coordinator and parking attendants who are at the forefront in the smooth running of this program. Self-managed operation and maintenance will not run well if Human Resources are not committed. One of these problems came to the fore because when improvements were made to the mechanism by the transportation agency, e.g., rotating parking attendants, many parties objected. One of the informants said that if a management scheme is still carried out by the government, these problems will remain unsolved.
Furthermore, public awareness of the use of electronic parking is still low. It was evident from observations made in one week. In our observation, only one or two people made payments electronically. This also concerns the seriousness of the government in providing services. Audits have been carried out at several points. However, two problems were underlying this matter. First, not many people have an e-toll card. Second, parking attendants cannot carry out their role optimally as an extension of the transportation service officer. The parking attendant directs each community to process transactions with electronic parking. If they do not follow directions, they will be subject to sanctions.

The next challenge is that the leadership of the regional head plays also an important factor in the smooth implementation of policies. Until the end of his tenure as mayor, Ridwan Kamil continued to monitor the development of electronic parking so that it could be implemented even though his leadership style tended to be top-down, and had to follow the directions of the policy choices he had made. This was revealed in an interview with one of the informants that the head of the department asked the head of the UPT Parking to directly collect the sector heads (kator) and the parking attendant coordinators. "After giving an understanding of the parking vision, I gave a semi-authoritarian direction. This is done because this kind of training is not the first time".

Apart from challenges, the unexplored potential of parking management with 445 electronic parking machines could be a facility to boost revenue growth. It can be seen from the condition of Bandung as a provincial capital with an urban culture, which certainly makes it very easy to socialize and adapt to behavior change.

In addition, another opportunity is the political support provided by the Regional People's Representative Council of Bandung City (DPRD) to improve the parking management system so that it can increase Regional Fixed Income (PAD). In the beginning, what prompted the purchase of parking machines was indeed driven by a university study in collaboration with members of the DPRD of Bandung City. During the discussion of the Mayor's Accountability Report (LPJ), there was a discussion on the parking machine budget of Rp. 80 billion. It turned out that the budget was the result of discussions with the DPRD Budget Agency. The discussion was aimed at following up and supporting the achievement of the results of the study which stated that the potential for onstreet parking in the city of Bandung reached Rp. 80 billion.

At that time, it coincided with the replacement of the Head of the Transportation Service. The decision is that the new Head of the Transportation Agency may not cancel policies that have been mutually agreed upon. As a result, the procurement of Rp. 53 billion was carried out and the rest was for operations.

The problem occurred after being installed at the end of 2016, the parking machine did not immediately operate. The argument of the head of the department at that time was not getting sufficient information. To be operational, it turns out 
that there must be an additional process of procuring an integrator, reader, and of course cooperation with banks holding electronic money.

The 2017 budget approval had been carried out and it was not budgeted. Therefore, the budget was rearranged in March 2017. The budget execution process was carried out afterward so that new readers and integrator services could start contracts in June. So that in July the parking machine operated.

At the year-end income from the management of electronic parking, which began in July, it only increased Rp. 1 billion from the previous year. It was from a figure close to Rp. 5 billion to close to Rp. 6 billion, and it was far from the target expectation of 80 billion.

At the beginning of 2018, it experienced a cumulative increase. However, in the following month, it did not increase or even fell. Subsequently, a field audit was conducted and after the audit was carried out it turned out that almost all the points violated procedure and every vehicle owner pays in cash.

Subsequently, the head of the department stopped the audit and then focused on the formation of the Regional Public Service Agency (BLUD) and changes to regional regulations on the implementation of transportation. The institutional change from the Parking Technical Implementation Unit (UPT) to the Public Service Agency is a step towards a more flexible management direction. Because in the Public-Private Partnership scheme, flexibility is needed in conducting governance. The government has issued Law Number 23 of 2005 concerning Financial Management of Public Service Bodies which stated that: "Public Service Bodies are agencies within the Government which are formed to provide services to the public in the form of providing goods and/or services that are sold without prioritizing profit-seeking and in carrying out its activities".

\section{B. Public-Private Partnership Schemes}

In the concept of New public management, the market mechanism is used in the utilization of the public sector. Whereas in conducting relations between government agencies and their customers, it is understood the same as the process of transaction relations carried out in the marketplace. By transforming market performance like this, on the other hands, it will replace or reform the public sector performance habits from a rule-based tradition and processes authority-driven processes to market -based orientation, and healthy competition [9].

To be more professional and in line with the concept of NPM, the Public-Private Partnership scheme needs to be considered. This scheme is most likely to renew the parking management system. Surely, it must be followed by several changes such as:

\section{Regulation}

The legal regulation being used in parking management nowadays is the local Regulation of Bandung city Number 4 of 2017 concerning the Implementation of Transportation and Retribution in the field of Transportation. This regulation requires $100 \%$ of all revenues and levies to go to the regional treasury and when there is an investment auction for parking machines they are paid from the APBD. Because it is paid for by APBD spending, Investors are subject to a $10 \%$ Value Added Tax (VAT). In addition, when negotiating with banks that provide cashless facilities, they said that they did not provide transaction services because retribution income must enter $100 \%$.

Thus, based on the informants' arguments, when there is a public-private cooperation scheme, several regulations must be changed, including those related to user charges. According to him, the concept of user fees does not provide flexibility in conducting market orientation.

\section{Institutional Transformation}

To improve the public services, a fundamental institutional arrangement is needed, i.e., by changing the Technical Implementation Unit (UPT) which is very bureaucratic and every process in carrying out service work relies heavily on the authority of officials.

In 2020, changes in parking management have begun by changing the nomenclature of the UPT to become a Regional Public Service Agency (BLUD) for Parking. Consequently, BLUD's way of working must be based on the principles of efficiency and productivity. Furthermore, the Public Service Agency Financial Management Pattern hereinafter referred to as PPK-BLU, is a financial management pattern that provides flexibility in implementing sound business practices to improve services to the community to advance public welfare and educate the nation's life.

The Technical Implementation Unit (UPT) or Regional Technical Implementation Unit (UPTD) that has become a BLUD has differences in managing its operational activities. These operational activities include financial management, Human Resources (HR), procurement of goods and services, and so on. After becoming a BLUD, several things need to be prepared by the UPT to be implemented concerning the management of its operational activities. The formulation of this Regional Head Regulation is carried out by the management of the Regional Public Service Agency (BLUD). They compile A Regional Head Decree (SK) for several things that support the operational management of the UPT and Prepare a BLUD Head Regulation, including regulating the appointment of a Treasurer for Revenue and Expenditure Treasurer from Non-APBD / APBN and other necessary regulations in accordance with the needs of each BLUD. Based on the information, even though it has become a BLUD, there are still some regulations that have not been fulfilled so that it is still not possible to collaborate with third parties. 


\section{E. Relations Between Parties}

Public-private cooperation schemes must pay attention to the relationships between the parties involved in the electronic parking management policy. The form of cooperation is a review so that the PPP partnership is structured to optimize value for the public and at the same time does not reduce interest from private partners. In general, this Form of Cooperation is carried out as part of a Feasibility Study. Reflecting on the initial procurement of a parking machine, which was to be carried out under the investment auction scheme, there was a lot of negotiations with business calculations with direct revenue sharing of $70 \%$ for investors because $30 \%$ of equipment providers went to the regional treasury. It was found that the retribution income cannot be shared with other parties.

Because the conditions have changed recently, it is possible to carry out the investment auction scheme again but only for parking management. The informant said that as long as it was not managed by a third party, the revenue from parking was still stagnant. On the other hand, if it is managed professionally by a third party such as DKI Jakarta, the income can be up to 4 times.

The relationship between the parties must also consider the risk mitigation that will occur. An in-depth feasibility study needs to be conducted. Therefore, there are no more processes that suddenly appear without prior thought. All are based on mature calculations with a win-win solution approach

\section{CONCLUSION}

It can be concluded that Electronic parking is an innovation made by the Bandung City government. Yet, this innovation was not followed by a change in governance. Since the beginning of the operation of the electronic parking machine in mid-2017, it did not provide a significant increase in retribution revenue because it was constrained by user community awareness, the commitment of field officers, and rigid institutions. Thus, the Bandung City Government must have the courage to make changes towards the New Public Management Paradigm model to open space in government management by collaborating with the Public-Private Cooperation scheme.

The prerequisites for running the scheme must pay attention to several things as the following:

\section{A. Regulation}

The existence of the PPP Scheme requires changes in regulations to facilitate cooperation, including those related to fees that must be converted into services

\section{B. Institutional Transformation}

The current change from UPT Parking to Parking BLUD is appropriate and must be followed by changes in regulations that become legal regulation

\section{Relations Between Parties}

The relationship between the parties must consider the risk mitigation that will occur. An in-depth feasibility study needs to be conducted.

\section{REFERENCES}

[1] D.F. Ramdani and F. Habibi, "Penguatan Partisipasi Masyarakat Dalam Mendorong Program Smart City di Kota Bandung," Prosiding Seminar Nasional Riset Terapan | SENASSET, pp. 125-129, 2017.

[2] M.R. Ghurobi, Kerjasama Pemerintah Swasta: Pola Pengembangan dan Faktor Penentu Keberhasilan. Universitas Airlangga, 2014

[3] H. Casnoto, "Pembiayaan Pembangunan Infrastruktur pada Daerah Otonom melalui Skema Kerjasama Pemerintah dan Badan Usaha Public Private Partnership Scheme in Local Government Infrastructure Development (Case Study in the Government of Bandung Municipality)," 2017

[4] P. Hartman, J. Ogden, and R. Jackson, "Contract duration: Barrier or bridge to successful public-private partnerships?" Technology in Society, vol. 63, p. 101403, 2020.

[5] J. Miranda and L. Renneboog, "Renegotiating public-private partnerships," Journal of Multinational Financial Management, p. 100661,2020

[6] F. Kirschner and M. Lanzendorf, "Support for innovative on-street parking policies: empirical evidence from an urban neighborhood," Journal of Transport Geography, vol. 85, p. 102726, 2020.

[7] H. Wang, R. Li, X.C. Wang, and P. Shang, "Effect of on-street parking pricing policies on parking characteristics: A case study of Nanning," Transportation Research Part A: Policy and Practice, vol. 137, pp. 6578, 2020.

[8] L.J. Moleong, Metodelogi penelitian. Bandung: Penerbit Remaja Rosdakarya, 2004

[9] S. Mulyani, "Kerjasama Publik dan Swasta dalam Pengelolaan Parkir di Objek Wisata Taman Kyai Langgeng Kota Magelang," Ilmu Administrasi Negara, vol. 1, no. 1, pp. 37-45, 2017. 